\title{
BUSINESS IMAGE AND STRATEGIES IN ROMANIAN AGRITOURISM
}

\author{
Iasmina Iosim*, Gabriela Popescu, Anka Suba, Claudia Sirbulescu \\ Banat's University of Agricultural Sciences and Veterinary Medicine "King Michael I of \\ Romania" from Timisoara \\ Faculty of Management and Rural Tourism \\ Calea Aradului, no.119, 300645, Timisoara, Romania \\ *Corresponding author: iasminaiosim@usab-tm.ro
}

\begin{abstract}
Business image is a paramount when it comes to improve a company's desirability as a borrower, client, customer, employer, supplier, etc. The most important strategies to build up business image are creating a website, creating straightforward, easy-to-understand pricing, designing the business image, doing a referral exchange, encouraging personal recommendations, listing creatively and widely, maintaining a customer database, maintaining good employee relations, making a marketing plan, making the business look good, naming and branding, and using the press. The paper presents the most important strategies illustrated by three Romanian agritourism guesthouses.
\end{abstract}

Keywords: business, image, strategies, communication, agritourism

\section{INTRODUCTION}

Business dictionaries define business / corporate / organisation image as a "Mental picture that springs up at the mention of a firm's name. [...] a composite psychological impression that continually changes with the firm's circumstances, media coverage, performance, pronouncements, etc. [...] the public perception of the firm rather than a reflection of its actual state or position." (BUSINESS DICTIONARY,) It is similar to a firm's goodwill or reputation It differs from corporate identity because "it is fluid and can change overnight from positive to negative to neutral" (BUSINESS DICTIONARY).

Companies use various corporate advertising techniques to enhance their image in order to improve their desirability as a borrower, customer, employer, supplier, etc.

Strategy is defined by business dictionaries as " 1 . A method or plan chosen to bring about a desired future, such as achievement of a goal or solution to a problem. 2. The art and science of planning and marshalling resources for their most efficient and effective use." (BUSINESS DICTIONARY).

Corporate / organisational image can be defined from two different perspectives (DUTTON, DUKERICH \& HARQUAIL, 1994):

- As perceptions of internal members, a "communicated image", a "construed external image", a descriptive view referring to how insiders believe external audiences view their organization (GIOIA, SCHUlTZ \& CORLEY, 2000);

- As perceptions of external members, a "projective view", "outsiders' beliefs about what distinguishes an organization" (DUTTON, DUKERICH, \& HARQUAIL, 1994, 243), encompassing the "characteristics organizational elites want stakeholders to ascribe to the firm" and (GIOIA \& THOMAS, 1996, IN MASSEY, 2003) (see also DI MARINO, 2008).

Corporate image needs developing and managing for the following reasons (ADENIJI et al., 2013): 
- Creating good identity for the employees, thus leading to their satisfaction;

- Enhancing corporate competitive advantage, thus leading to higher profitability;

- Establishing a corporate goodwill for the organisation;

- Influencing investors and financial institutions;

- Promoting favourable relationship with the community in the environment the organisation operates to avoid difficulty in recruitment, selection and maintaining the employee morale;

- Promoting good relationship with the government, opinion leaders and various interest groups;

- Stimulating sales, thus influencing customer loyalty.

\section{MATERIALS AND METHODS}

The research methods consisted in consulting a specialized literature on the marketing communications mix in agritourism, books, websites, and comparative analysis.

Nevertheless, the research method is a descriptive one: it "seeks to describe a situation, and more precisely, when it comes to marketing, to describe a marketing mix" (MISHRA, 2008, IN JOLY \& TOUS, 2012). The analysis has been done based on websites advertising for guesthouses practicing agritourism in rural Romania (Casa Wia Rusti, Brașov County, https://wiarusti.ro; La Roata, Suceava County, https://www.la-roata.ro; and Manoir Mignon, a four-star hotel B\&B in Suceava County).

\section{RESULTS}

After studying the literature on the building up strategies for business / corporate / organisation image, twelve strategies have come out repeatedly (YOUR BUSINESS IMAGE: TEN WAYS TO BUILD AND MARKET IT).

1. Creating a website. In the era of ICTs, a website is a must: if a business does not have a website, it does not exist for the business environment. A good website has a professional look and feel that suits the business. There are several advantages of having a website for one's business:

- It allows advertising through Facebook ads, SEO (Search Engine Optimisation) service provider, etc.;

- It can be attractive with a blog page to post fresh content;

- It can be extremely valuable due to its links;

- It can help build better relationships with the customers (the company sends messages to its customers, and the customers send feedback to the company);

- It can help ensure long-term customers;

- It can help generate more customers outside the business' city and worldwide;

- It can help increase sales by consistently updating and promoting its content;

- It gives the business the opportunity to prove its credibility;

- It is accessible 24/7;

- It is less expensive (sometimes even free of charge) than the printed media, radio, TV, etc.;

- It is more convenient for customers and leads;

- It provides information on what happens on it (number of visitors, messages, and e-mails; updates; website progress).

The website page dedicated to agritourism in Romania (AgROTURISMUL ÎN ROMÂNIA) presents three guesthouses in the rural area (Casa Wia Rusti, Braşov County; La Roata, 
Suceava County; and Manoir Mignon, Suceava County), all of which have their own website with minimum information about accommodation food, or attractions.

2. Creating Straightforward, Easy-To-Understand Pricing. Price strategies are impacted by corporate image, discounts, geography, price discrimination, price sensitivity. External corporate image affects its ability of adopting a specific price strategy (for instance, a midmarket supermarket chain would find it difficult to move up market in price; a low-cost automobiles producer would find it extremely difficult to move up to an image of luxury cars producer) (SAMMUT-BONNICI \& CHANNON, 2015). Pricing strategies (such as bundle pricing, captive pricing, economy pricing, geographical pricing, price skimming, pricing at a premium, pricing for market penetration, promotional pricing, psychological pricing, and value pricing - cf. SCOTT, 2019) should take into account - besides account segments, competitors' actions, consumers' ability to pay, distribution costs, input costs, market conditions, production costs, trade margins, and variable costs (SCOTT, 2019) - Internet pricing disparity, manufacturers selling costs and trade allowances, price optimization modelling, and retail consolidation. On the other hand, pricing strategies have a considerable impact on consumer pressure groups, government agencies, regulatory authorities, shareholders, etc. Many businesses use complicated pricing structures and try to hide their prices from their customers. Or, service businesses, for example, should streamline and make their pricing clear (i.e., tell the customers exactly how much they should expect to pay for every particular service with the help of a pricing menu).

The website of Casa Wia Rusti supplies information about the price for the three types of accommodation provided (twin room, triple room, and suite) except for a substantial accommodation discount for those who opt for a private tour, but no detail about the price for food, except the mention that they can cater for orders above 100 Ron. The website of Manoir Mignon supplies information about the tariffs in Euros for each type of accommodation (single room, twin room, suite jr., and suite), and offers a discount of $12 \%$ or minimum two nights or tourist groups of eight people. The website of La Roata Guesthouse supplies no details regarding the price of accommodation or food, but mentions that holiday vouchers (paper or card) are accepted!

3. Designing the Business Image. Graphic design concerns the overall visual presentation of the organisation, i.e., "visual identification" (GRAY \& BALMER, 1998): design style of the company's literature, signs and stationery; number of logos; style of the colouring, illustrations, layout, photography, typeface, and type of logos. Among these visual identification elements, the logo is the heart of the corporate graphics design system: it can be changed over time to reflect the evolving, modernising corporate identity. A company's visual presentation may not always appropriately communicate its identity.

This is the image (logos \& photos) of the three studied guesthouses (Figure 1).

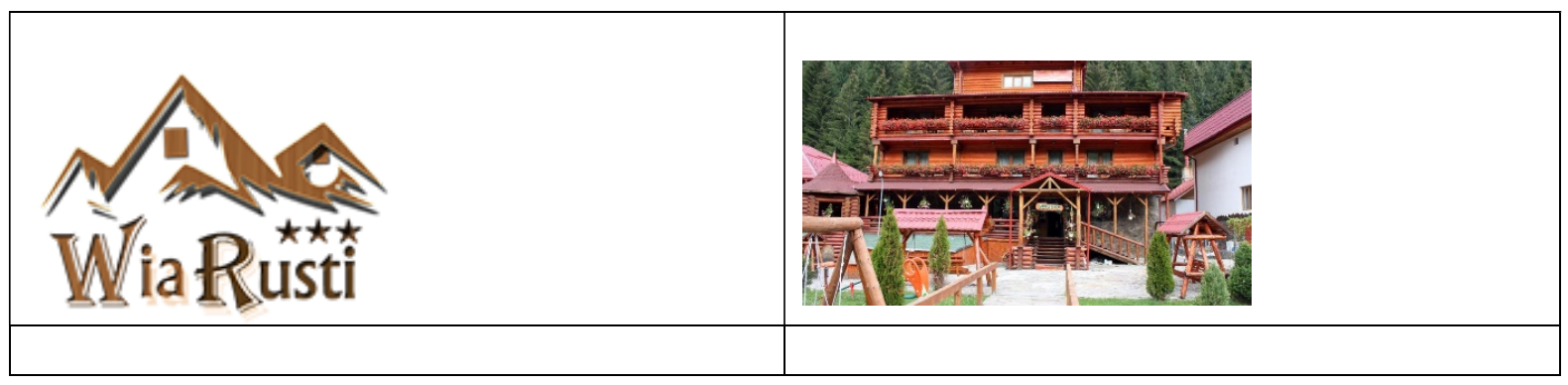




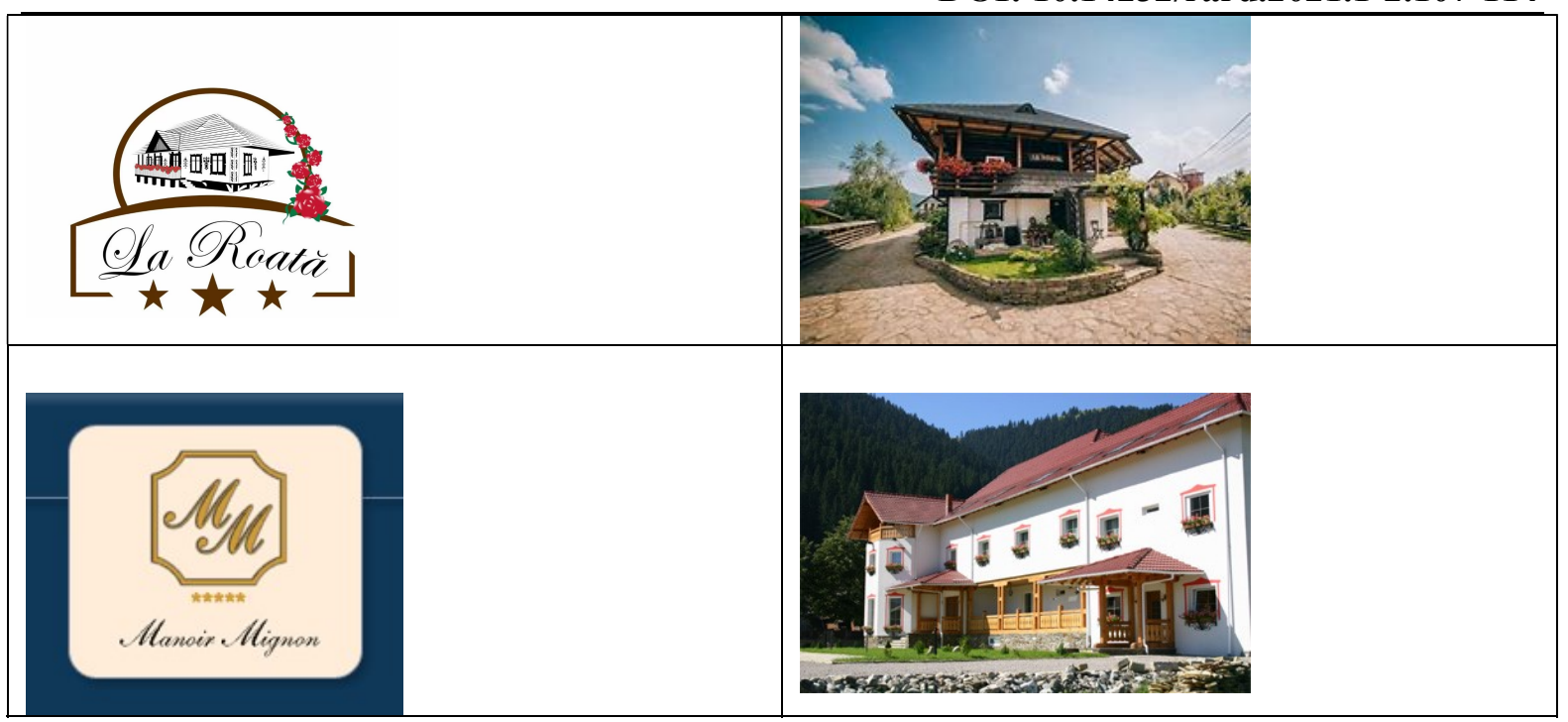

Figure 1. Guesthouses Casa Wia Rusti, La Roata, Manoir Mignon image (sources: https://wiarusti.ro, https://www.la-roata.ro, www.manoirmignon.ro)

4. Doing a Referral Exchange. Two related business (e.g., chiropractors and massage therapists, dentists and orthodontists, financial planners and tax preparers) may refer clients to each other. In this case, they should set up an exchange by:

- Placing brochures / cards at the second business's office / store;

- Displaying the other business's marketing materials in the first business's place of business.

This strategy seems to be unidirectional. Thus, the website of Casa Wia Rusti shows no sign of referral exchange, but it mentions that the guesthouse is $10 \mathrm{~km}$, far from the famous Bran Castle (however, Booking.com makes more references about the attractions of the area - Dino Parc, George Enescu Memorial House, Știrbey Castle). In exchange, the website of La Roata has a "Tourist Attractions" button suggesting leisure places (a ski slope, a swimming pool), local attractions (Suceava Fortress, Folk Crafts Museum), and monasteries (Gura Humorului, Moldovița, Sucevița, Voroneț) to visit during the stay. The website of Manoir Mignon suggests visiting the painted monasteries of Bucovina, the monasteries of Neamț County, and the wooden churches of Maramureș County.

5. Encouraging Personal Recommendations (referring a friend may get the business points, a $50 \%$ cut for a haircut, etc.) may be the best way to get new customers because almost nothing is more powerful than an endorsement from a friend / relative and it is free. Business referral may be done by:

- Amplifying the business product giveaways with social media;

- Building up the excitement;

- Establishing the business's authority with free webinars;

- Giving away awesome stuff;

- Helping an NGO do something good;

- Offering a taste with free premium access;

- Paying referrers for each referral;

- Rewarding referrers in credits;

- Rewarding referrers with the business's best stuff;

- Showing love with gift cards.

None of the three guesthouses seems to encourage personal recommendations. 
6. Listing Creatively and Widely is a great way to draw people to the business, and it is usually low-cost / free. Listing should be done:

- In not-so-obvious places (an NGO listing of businesses with good environmental and social practices, a website where parents make referrals about services for their children);

- In obvious places (Chamber of Commerce, Yellow Pages).

Casa Wia Rusti is listed on Booking.com (rating: 9.3 out of 10) and TripAdvisor (rating: 3.5 out of 5), and on Romanian tourism / travel websites (Direct Booking.ro, portal-info.ro, TURIST INFO.ro, etc.), and is also present on Facebook. La Roata is listed on Airbnb, Booking.com (rating: 9.6 out of 10), TripAdvisor (rating: 4.5 out of 5), Vrbo, and on Romanian tourism / travel websites (Discover Eco Romania), and is also present on Facebook and YouTube. Manoir Mignon is listed on TripAdvisor (rating: 3.5 out of 5) and on Romanian tourism / travel websites (cazarelapensiune.ro, Direct Booking.ro, pensiunidetop.ro, etc.).

7. Maintaining a Customer Database. A customer who used a business once and who had a good experience will be likely to use it again. It is less expensive to direct mail or e-mail promotions to customers in a customer database than to acquire a new customer. A complete customer's contact information should include: customer name, company name, work function, address, telephone, e-mail address, compiled address, estimated sale, last contact, lead status, lead source, product, and price per product unit (CUSTOMER RELATIONSHIP MANAGEMENT, 2013).

There is no data available on possible customer databases of any of the three guesthouses studied.

8. Maintaining Good Employee Relations. Employees who love their jobs and believe in the business they work for (because they are treated right): display / use / wear the business's merchandise or services and recommend the business to their families / friends. According to GRAY \& BALMER (1998), "[...] employees should be trained and motivated to project a positive image of the organisation", particularly in the case of service organisations (because, in this case, personal interactions are the key to customer satisfaction). Improving a business's employee relations involves (Strategies to Improve Employee Relations):

- Assigning individuals targets and asking all team members to contribute equally and achieve the target within the desired time frame;

- Encouraging effective communication among the team members;

- Encouraging individuals to share their work with each other;

- Involving the team members;

- Organising morning meetings;

- Organizing birthday parties, Christmas parties, New Year parties etc. at the workplace;

- Praising the individuals if they have done something exceptionally well;

- Rewarding the individuals if they have done something exceptionally well;

- Trying one's level best that all the employees must have their lunch together at the same time;

- Writing modes of communication must be promoted among the employees for better transparency.

There is no data available on maintaining good employee relations of any of the three guesthouses studied but, given that they are all family businesses, this does not seem to be an issue.

9. Making a Marketing Plan. A formal marketing plan should:

- Check back regularly to track the business's progress; 
- Determine how and when specific performance goals will be met;

- Include an analysis of the business's competitors;

- Include an analysis of the business's market;

- Include marketing ideas (on business marketing, press releases, referral program, website);

- Include marketing objectives;

- Outline the business's marketing budget;

- Outline the business's mission;

- Set specific performance goals.

Given that the three guesthouses have managed to be in business over the years, it seems that they all had good marketing plans.

10. Making the Business Look Good. A solid, strong physical impression making the business credible and inviting customers in may benefit, depending on the type of business, from a brochure, an office (tastefully decorated with business furniture and wellorganized), a store front, a veterinary's practice (a whimsical design with bright colours and fun murals on the wall), or a website. Depending on the cultural environment of a business, the interior layout of offices may suggest different things: in the case of a large open room with desks in full sight of each other - openness; a series of closed offices lack of openness (GRAY \& BALMER, 1998). As shown in Figure 1, all three guesthouses look good.

11. Naming and Branding. The names used to identify an organisation, its divisions and its products are extremely important. They can be changed over time to reflect the evolving, modernising corporate identity, just like the logos (GRAY \& BALMER, 1998). In another order of ideas, organisations may operate under different names if they have a portfolio of unrelated businesses, or if their subsidies have distinct / better-known names than the parent organisation.

Figure 1 above shows the logos of the three guesthouses. To note that only the logos of guesthouses Casa Wia Rusti and La Roata suggest rurality.

12. Using the Press. In large corporations, media relations are managed by a PR department, while, in smear companies, they are typically handled informally by senior management (GRAY \& BALMER, 1998). In public relations, the publics are competitors, consumers, courts, financial institutions, general, government, interest groups, media, public employees, scientific community, shareholders, suppliers, etc. (SINGH \& PANDEY, 2017). A simple press release on a newsworthy angle on the business (e.g., a business grand opening, a business "story", why the business's offer is different) sent to local publications may be inexpensive, but it is effective, particularly in case of unfavourable rumours and stories (AGYAPONG, TWUM-AMPOMAH \& ACHEAMPONG, 2015). Other appropriate communication channels are open days, press conferences (weekly, monthly, quarterly, bi-annual), Short Messages Service (SMS) number, etc. (ANYANGO, 2006). Public relations are particularly important for corporate image in crisis situations (Ferguson, Wallace \& ChandLer, 2012).

There is no data available on using the press by any of the three guesthouses studied.

\section{DISCUSSION}

Of the twelve corporate image building-up strategies listed above, the ones used by the three agritourism guesthouses studied are: creating a website, designing the business image, doing a referral exchange, listing creatively and widely, making the business look good, and naming and branding. Pricing strategies as a strategy is not very transparent. 
While making a marketing plan and using the press are not explicit strategies, but have implicit effects, there is no evidence whatsoever regarding such strategies as encouraging personal recommendations, maintaining a customer database, or maintaining good employee relations (though they might play an important role in the businesses investigated here).

It would be better for the corporate image of the agritourism guesthouses investigated above to insist on the local attractions because tourists need more than just a bed to sleep and a table to eat when practicing agritourism. Cultural tourism might add value to the holidays and differentiate an agritourism location from other similar ones.

\section{REFERENCES}

Adeniji, A. A., Osibanjo, A. Omotayo, A., Abolaji, I. \& Oni-Ojo, E. E. (2013). Corporate Image: A Strategy for Enhancing Customer Loyalty and Profitability. Journal of South African Business Research, 1-13.https://doi.org:10.5171/2015.259483

Agyapong, K., Twum-Ampomah, M. K. \& Acheampong, A. (2015). Using Public Relations Tools to Build Image of Tertiary Institutions. International Research Journal of Marketing and Economics, 2(5), 1-18.

Anyango, M. D. (2006). The Role of Public Relations in the Building the Image of the Kenyan Judicial System. MA Research Project. Nairobi: University of Nairobi.

Business Dictionary. Available online: http://www.businessdictionary.com. Accessed on July 15, 2019.

Casa Wia Rusti. Available at: https://wiarusti.ro. Accessed on January 8, 2021.

Customer Relationship Management. (2013). Ontario: Queen's Printer for Ontario.

Di Marino, E. (2008). The Strategic Dimension of Destination Image. An Analysis of The French Riviera Image from The Italian Tourists' Perceptions. PhD Thesis. Napoli: Università degli Studi di Napoli Federico II.

Dutton, J. E., Dukerich, J. M. \& Harquail, C. V. (1994). Organizational Images and Member Identification. Administrative Science Quarterly, 39(2), 239-263. https://doi.org/10.2307/2393235

Ferguson, D. P., Wallace, J. D. \& Chandler, R. C. (2012). Rehabilitating Your Organization's Image. Public Relations Professionals' Perceptions of the Effectiveness and Ethicality of Image Repair Strategies in Crisis Situations. Public Relations Journal, 6(1), 1-19.

Gioia, D. A., Schultz, M. \& Corley, K. G. (2000). Organizational Identity, Image, and Adaptive Instability. Academy of Management Review, 25(1), 63-81. https://doi.org $/ 10.2307 / 259263$

Gray, E. R. \& Balmer, J. M. (1998). Managing Corporate Image and Corporate Reputation. Long Range Planning, 31(5), 695-702.https://doi.org/10.1016/S0024-6301(98)00074-0

Joly, L. \& Tous, G. (2012). The Role of Communication in the Repositioning Strategy of a Tourism Destination. A Case Study of a French Ski Resort: Avoriaz. BA Dissertation. Halmstad: University of Halmstad.

Massey, J. E. (2003). A Theory of Organizational Image Management: Antecedents, Processes \& Outcomes. International Academy of Business Disciplines Annual Conference, Orlando, FL, April, 2003. 1-19.

Sammut-Bonnici, T. \& Channon, D. F. (2015). Pricing Strategy. In Cary I. Cooper (ed.), Wiley Encyclopedia of Management. New York, NY: John Wiley \& Sons.https://doi.org/10.1002/9781118785317.weom120162 
Singh, N. \& Pandey, R. (2017). Role of Public Relations in Image Management of an Organisation. International Journal of Advance Research, Ideas and Innovations in Technology, 3(4), 164-168.

***La Roata. Available at: https://www.la-roata.ro. Accessed on January 8, 2021.

$* * *$ Manoir Mignon. Available at: www.manoirmignon.ro. Accessed on January 8, 2021.

$* * *$ Scott, C. (2019). How to Choose A Pricing Strategy for Your Small Business. Available at: https://quickbooks.intuit.com/r/pricing-strategy/6-different-pricingstrategies-which-is-right-for-your-business/. Accessed o 10.11.2019. 